\title{
Controversies that have been fabricated. From tobacco smoke to global warming
}

\author{
Ewa Binczyk \\ Nicolaus Copernicus University, Torun, Poland
}

\begin{abstract}
The text is a short note on a book entitled "Merchants of Doubt: How a Handful of Scientists Obscured the Truth on Issues from Tobacco Smoke to Global Warming", written by Naomi Oreskes and Eric M. Conway.
\end{abstract}

KEY WORDS: global warming denial movement, science and technology studies, disinformation campaigns, merchandizing of doubt.

ADDRESS FOR CORRESPONDENCE: Ewa Binczyk, Nicolaus Copernicus University, 1 A Fosa Staromiejska, 87-100 Torun,

Poland, e-mail: Ewa.Binczyk@umk.pl

In 1992, 25\% of Americans did not believe at all that smoking is harmful for your health [1, pp. 33, 241]. Between 2007 and 2011, the percentage of Americans convinced that burning fossil fuels causes climate change dropped from $71 \%$ to $44 \%$. As the Pew Research Center underlines, it was one of the biggest changes of public opinion ever documented, that happened in such a short time [2]. How was it possible?

To answer this question, we need to familiarize ourselves with the spectacular examples of successful disinformation campaigns, exposed and analyzed within the last decade by scientists, mainly within the field of the so-called Science and Technology Studies (STS). As they conclude, the activity of tobacco industry and global warming denial movement represent a broader phenomenon called "product defense industry", "merchandizing of doubts", and "fabricating controversies" $[3,4]$.

'Merchants of Doubt: How a Handful of Scientists Obscured the Truth on Issues from Tobacco Smoke to Global Warming' [1] provides us with rich and well-documented empirical material referring to this subject. Two brilliant historians of science, Naomi Oreskes and Eric M. Conway, spent several years analyzing thousands of pages of documents to expose the mechanisms, financial conditions, and the main actors of the most harmful denialisms of the XX century.

Research of this kind have become possible after a series of court trials against the tobacco industry in the

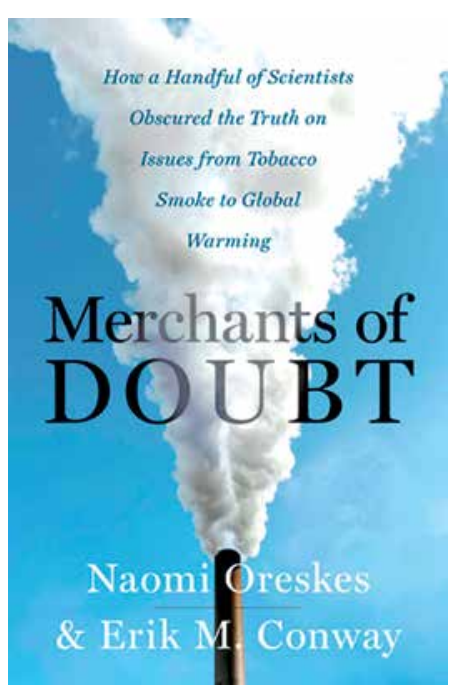

USA. In the 90. of the XX century, the Legacy Tobacco Documents Library was made available to the public by the University of California, San Francisco. It is currently an archive of 14 million documents created by tobacco companies about their scientific research and cooperation, advertising policies, manufacturing, and marketing [1].

Today we know that the representatives of tobacco industry were perfectly aware of a carcinogenic effect of smoking tobacco as early as in the 50. of the XX century. In case of U.S. vs. Philip Morris Inc. et al., the sentence was passed exactly because the corporation kept this 
knowledge secret (RICO Act: Racketeer Influenced and Corrupt Organizations) [1, pp. 31-33].

Oreskes and Conway depicted the manufacturing of doubts and fabricating controversies in relation to a variety of problems: the highly addictive nature of nicotine, the problem of passive smoking, the toxicity of acid rains, the health risks of DDT and asbestos, and the negative effects of CFC on the ozone hole. Their book describes the antiregulatory discourse in the USA and the rhetoric undermining the activity of Environmental Protection Agency (EPA).

American scholars disclose the disgraceful role of experts, media, think tanks and quasi-scientific institutes, financed by corporate money of Exxon Mobile or Philip Morris Corporation, such as Cato Institute, Competitive Enterprise Institute, Heartland Institute, Fox News and "The Wall Street Journal" [1, pp. 216-239].

What the most important feature of the book is that both the authors defend the authority of science, its basic epistemological rules of peer review, and institutional mechanisms of professionalism. While writing about denial strategies, they revealed the negative role of the leading conservative media in the USA. Journalists fail to remain impartial, mislead by the ethical rule of impartiality and symmetry of opinions, which in many cases constitute a serious informational bias. There is practically no controversy among climate scientists. $97 \%$ of them consider the anthropogenic climate change a fact, but for a long time the issue had been presented as a problematic one. At least $50 \%$ of time and space in press, radio, and television had been offered to climate sceptics, who represent only $3 \%$ of the scientific community of climatologists.

\section{DISCLOSURE}

Author reports no conflict of interest.

\section{References}

1. Oreskes N, Conway EM. Merchants of Doubt: How a Handful of Scientists Obscured the Truth on Issues from Tobacco Smoke to Global Warming. Bloomsbury Press, New York 2010.

2. The Pew Research Center. 2011. Modest Rise in Number Saying There is 'Solid Evidence' of Global Warming. Available from: http://www.people-press.org/files/legacy-pdf/12-1-11\%20Global\%20warming\%20release.pdf (accessed 2 November 2015).

3. Proctor RN. Cancer Wars: How Politics Shapes What We Know and Don't Know about Cancer. Basic Books, New York 1995.

4. Wynne B. When Doubt Becomes a Weapon. Nature 2010; 466: 441-442.

Dr. Naomi Oreskes is professor of the history of science and affiliated professor of Earth and planetary sciences at Harvard University, and an internationally renowned geologist, science historian, and author. She received a B.Sc. (First Class Honours) in Mining Geology from the Royal School of Mines, Imperial College, London (1981) and then worked as an exploration geologist in the Australian outback. In 1990 she received an interdisciplinary Ph.D. in Geological Research and History of Science from Stanford University. She joined the faculty at Harvard in 2013 after 15 years at the University of California, San Diego.

Professor Oreskes is the author of both scholarly and popular books and articles on the history of earth and environmental science, including The Rejection of Continental Drift (Oxford, 1999), Plate Tectonics: An Insider's History of the Modern Theory of the Earth (Westview, 2003), and in recent decades has been a leading voice on the issue of anthropogenic climate change. Her 2010 book, Merchants of Doubt: How a Handful of Scientists Obscured the Truth on Issues from Tobacco to Global Warming, co-authored with Erik M. Conway, was shortlisted for the Los Angeles Times Book Prize won the Watson-Davis Prize from the History of Science Society, and has been translated into eight languages. The film version, by the same name and produced by Robby Kenner and Participant Media, was released by SONY Classics Pictures in 2015.

Oreskes and Conway have also written The Collapse of Western Civilization (Columbia University Press, 2014), which has been a best seller in France, and has been translated into nine languages. In 2016, she was awarded the Stephen H. Schneider Award for Outstanding Climate Science Communication, and became an Ambassador of the American Geophysical Union. She also serves on the Board of Protect Our Winters, a non-profit that works with the winter sports community to promote awareness and action on climate change.

Ewa Binczyk, the author of the above article, is professor of the Nicolas Copernicus University in Torun and currently a visiting scholar at Harvard University (Department of the History of Science). She obtained PhD in philosophy in 2004 and degree of habilitation in philosophy of science in 2013 at the NCU. 